\title{
NO. 205
}

DECEMBER

2021

\section{ADB BRIEFS}

\section{KEY POINTS}

- Migrants from Tajikistan face challenges stemming from the lack of timely and adequate information on legal channels of migration, labor conditions, and regulations in destination countries.

- As international labor markets gradually reopen for migrants toward the post-COVID-19 era, the Government of Tajikistan needs to strengthen its delivery of predeparture services for potential migrants.

- Advanced predeparture services for labor migrants from other origin countries in Asia may offer insights for enhancing these services, such as by (i) establishing strategic program design and management, (ii) adopting effective training approaches, (iii) leveraging digital and technological solutions, and (iv) embracing a multistakeholder and inclusive approach.

- In the medium and long terms, the Government of Tajikistan could establish a standard departure process for Tajik migrants in consultation with destination countries. The government could also develop and provide comprehensive migrant support services, including digital and online resources.

\section{Strengthening Predeparture Services for Labor Migrants in Tajikistan Post-COVID-19}

\author{
Takashi Yamano \\ Principal Economist \\ Economic Research and Regional \\ Cooperation Department \\ Asian Development Bank (ADB)
}

Aiko Kikkawa

Economist

Economic Research and Regional

Cooperation Department $\mathrm{ADB}$

\author{
Eiko Kanzaki Izawa \\ Specially Appointed Professor \\ St. Andrew's University, Japan \\ Nahreen Farjana \\ Independent Consultant
}

\author{
Raymond Gaspar \\ Consultant, ADB
}

\section{INTRODUCTION}

The coronavirus disease (COVID-19) pandemic caused a steep drop in the number of migrants from Tajikistan during the spring season in April and May 2020, although the number partly recovered in the second half of the year (Shimizutani and Yamada 2021). Prospective Tajik migrants were unable to travel and were forced to remain at home when major destination countries, including the Russian Federation, imposed lockdowns and closed their borders. The Ministry of Labor, Migration and Employment (MOLME) reported that the number of Tajik migrants who went abroad for work decreased by $57 \%$ in 2020 compared with the previous year.

The steady and growing number of international migrants from Tajikistan prior to the COVID-19 pandemic was largely attributable to the country's weak labor demand and low wages. From 2015 to 2018, an average of half a million people from Tajikistan were bound for overseas employment each year (ADB 2019). The migration remained predominantly seasonal in time for agriculture and construction activities in the Russian Federation from April to October. Seasonal migration is possible as Tajiks enjoy visa-free entry to the Russian Federation and can stay for 90 days, including for short-term work.

Migrant workers from Tajikistan are mostly young men; however, the demand for overseas work among women has been growing in recent years. Most male migrants work in lowskilled jobs in the construction sector, whereas most female migrants have low-skilled jobs 
in the services sector (JICA 2020). Many of these labor migrants are from rural areas and hold secondary education qualifications. Yet, Tajik migrants do not necessarily hold occupations that match their skills and qualifications as many of them accept any readily available job, and an increasing number of migrants come from non-Russian speaking households (ADB 2020b; Shimizutani and Yamada forthcoming). Finally, a growing number of Tajik migrants are listed on the Russian Federation's reentry ban list because they had violated laws while working in the country (ADB 2020b).

Effective predeparture service programs can assist Tajik migrants find jobs that match their skills, be aware of the laws in destination countries, and stay vigilant to malpractices against them. This brief examines the migration conditions of Tajik citizens and discusses effective predeparture services. It draws on a review of advanced predeparture services in selected countries in Asia.

\section{CHALLENGES AND ISSUES IN PREDEPARTURE SERVICES IN TAJIKISTAN}

Tajik migrant workers face several challenges at various stages of migration (figure), mainly stemming from a lack of awareness and training opportunities (ADB 2020b). During premigration, prospective migrants need to search for jobs abroad, study the conditions of their stay and residence in the destination country, prepare necessary travel documents, and improve their skills before departure. Although some information can be found online, ${ }^{1}$ public awareness of its availability remains weak.

To help prospective migrants, four centers in Tajikistan provide predeparture services. However, these centers lack resources to perform their intended function. For instance, the predeparture center in Dushanbe has only 14 staff, while the other three have fewer staff and lack basic equipment and facilities (ADB 2019).

Instead of structured predeparture orientation and training programs, these centers offer ad hoc consultation sessions organized upon request by potential migrants. These consultation sessions usually last 30-40 minutes during which migrants are given print materials that provide an overview of the laws and regulations for labor migrants to the Russian Federation (ADB 2020b).

Although short of staff, predeparture centers are also responsible for helping returned or returning migrants. Many of these migrants have been added to the Russian Federation's reentry ban list because they had violated laws ${ }^{2}$ while working in the country. By December 2019, the number of Tajik migrants reached 267,324 , only adding to and increasing the workload of predeparture centers (ADB 2020b).

\section{Issues Faced by Tajik Migrants in Different Migration Stages}
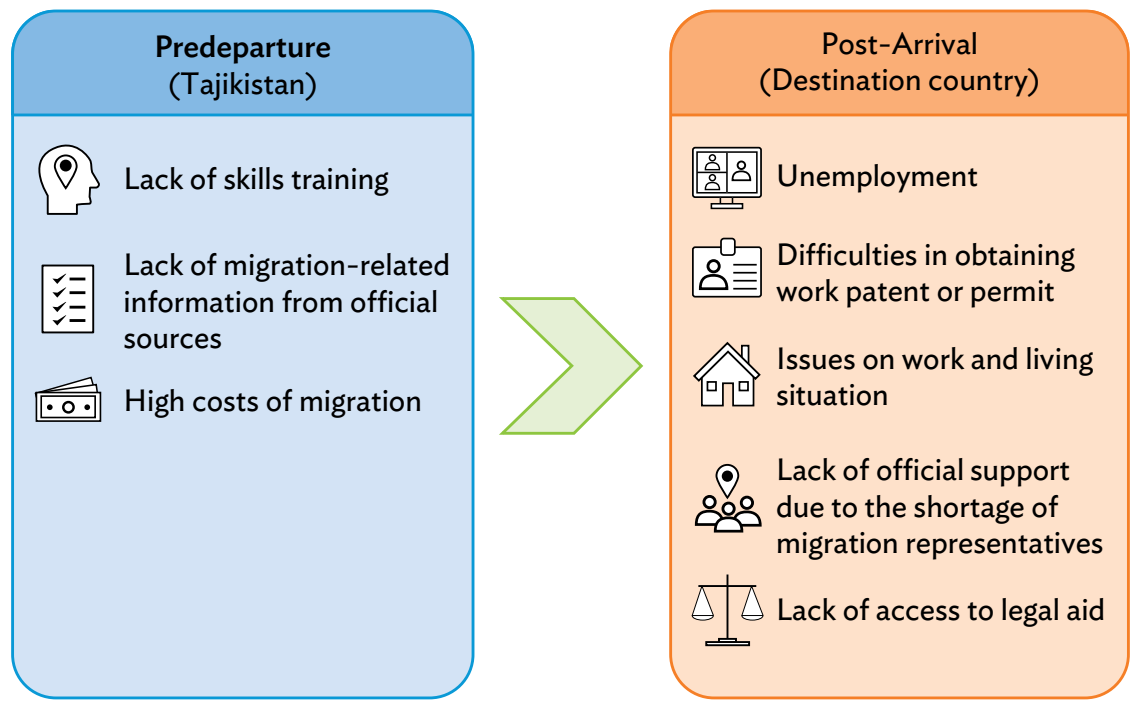

Source: Authors' illustration.

1 Publicly available information includes (1) migration services under the Ministry of Labor, Migration and Employment of Tajikistan, which provides information on: (i) departure to the Russian Federation; (ii) arrival in the Russian Federation; (iii) finding employment, (iv) procedure for obtaining a work permit; (v) legal aid, and more; (2) strengthening and development of protection mechanisms for Tajik migrants, which is implemented by the Center of Human Rights; and (3) a special initiative of Plus, which provides information on labor migration, especially for Tajik labor migrants in the Russian Federation.

2 Detailed information from the Russian Federation on the reentry ban is unavailable. 
A recent household survey performed by JICA (2020) found that migrants obtain information on predeparture preparation primarily from friends, relatives, family members, nongovernmental organizations (NGOs), individual brokers, and newspaper advertisements. The decision to migrate also comes at a high price involving travel, ${ }^{3}$ repayment of loans, as well as the cost of supporting the family left behind.

\section{RECOMMENDED PRACTICES FROM SELECTED ASIAN COUNTRIES}

The current predeparture services in Tajikistan give prospective Tajik migrants only limited guidance and knowledge of indemand skills in foreign labor markets, particularly in the Russian Federation. As a result, most migrants leave the country without proper knowledge of the rules and regulations associated with their stay abroad, as well as their rights and obligations (ADB 2019).

Tajik migrants tend to undertake work abroad with no skills training or any official recognition of their skills. Official skills certificates from Tajik authorities are recognized neither by the
Russian Federation nor by other authorities and employers of major destinations. In Dushanbe, a Russian language examination center offers online language examination and issues successful examinees with a certificate that is recognized in the Russian Federation. In addition, some language courses are available for free or at a low cost, although information on these are not always available.

The experiences of other Asian countries, such as Bangladesh, Indonesia, Sri Lanka, and the Philippines, offer insights toward modernizing and enhancing the effectiveness of Tajikistan's predeparture services. The evaluation of the effectiveness of predeparture orientation seminars (PDOS) provided to Filipino migrants departing for the United States (US) show positive short-term effects. Barsbai et al. (2016) found that relative to the migrants who received the standard PDOS, those who received the improved PDOS generally experienced fewer travel-related difficulties and problems relating to settlement such as obtaining a social security number and opening a bank account. ${ }^{4}$

Information dissemination and knowledge exchange practices in selected Asian countries that can also be applied in Tajikistan are presented in the table that follows.

\section{Summary of Predeparture Service Programs in Selected Asian Countries}

\begin{tabular}{|c|c|c|c|c|}
\hline & Bangladesh & Indonesia & Philippines & Sri Lanka \\
\hline $\begin{array}{l}\text { Name of predeparture } \\
\text { program }\end{array}$ & Predeparture briefing & $\begin{array}{l}\text { Predeparture } \\
\text { briefing (PAP) }\end{array}$ & $\begin{array}{l}\text { Predeparture orientation seminar } \\
\text { (PDOS) }\end{array}$ & $\begin{array}{l}\text { Predeparture } \\
\text { orientation }\end{array}$ \\
\hline Launched in & 1990 & 2003 & 1983 & $1996^{a}$ \\
\hline Implementing agency & BMET & BNP2TKI & $\begin{array}{l}\text { OWWA (since 2003; } \\
\text { previously POEA) }\end{array}$ & SLBFE \\
\hline Provider(s) & TTC (70) since 2017 under BMET & $\begin{array}{l}\text { BNP2TKI; BP2TKI } \\
\text { (in } 16 \text { provinces) }\end{array}$ & $\begin{array}{l}\text { OWWA; POEA; NGOs (for workers); } \\
\text { recruitment agencies (58); industry } \\
\text { associations }\end{array}$ & SLBFE \\
\hline Fees & $\begin{array}{l}\$ 2.35 \text { ( } 24 \text { hours); } \\
\$ 7.00 \text { (for FMDW) }\end{array}$ & None & $\begin{array}{l}\text { Government-none; } \\
\text { others-P100 (\$2.30) }\end{array}$ & None \\
\hline Registration & Mandatory & Not known & Mandatory & Mandatory \\
\hline PDO & Mandatory & Mandatory & Mandatory & Mandatory \\
\hline Length of program & $\begin{array}{l}24 \text { hours (since } 2017 \text { at the TTCs) and } \\
8 \text { hours at BMET for general migrants; } \\
30 \text { days for FMDW }\end{array}$ & 8 hours & 6 hours & Half-day \\
\hline
\end{tabular}

BMET = Bureau of Manpower, Employment, and Training; BNP2TKI = Badan Nasional Penempatan Dan Perlindungan Tenaga Kerja Indonesia (National Board for the Placement and Protection of Indonesian Overseas Workers); FMDW = female domestic workers; NGO = nongovernment organization; OWWA = Overseas Workers Welfare Administration; PDO = Predeparture Orientation; SLBFE = Sri Lanka Bureau of Foreign Employment; TTC = technical training center. aPDOS was made compulsory in 1996; no information is available as to when PDO programs began.

Source: Authors' compilation.

3 Among countries in the Commonwealth of Independent States, Tajikistan has the highest passport cost ( $\$ 37.4$ or $13.36 \%$ of per capita gross national income in 2005) (McKenzie 2005).

4 The new PDOS overhauls and extends the old PDOS by tackling issues beyond immediate needs, such as travel and immigration procedures. This addresses US-specific issues, such as employment, settlement, and building a support network, and comes with a comprehensive handbook that contains pertinent information (Barsbai 2018). 


\section{Establish strategic program design and management}

Bangladesh, Indonesia, the Philippines, and Sri Lanka hold PDOS that cover a wide range of topics, such as (i) migration requirements (medical tests, certification, and documentation); (ii) work contracts; (iii) immigration and flight procedures; (iv) working conditions, rules, and regulations, and culture and code of conduct in the destination country; ( $v$ ) workplace safety; (vi) access to support from the embassy, legal aid, and health and insurance in a foreign country; (vii) safe remittance and banking procedures; (viii) physical and psychological health; and (ix) return and reintegration challenges. In some cases, language training is also included in predeparture support, while in other cases, destination country-specific or occupation-specific seminars are provided.

Mandatory Predeparture Orientation (PDO) registration expedites proper documentation of migrants, which contributes to safer migration and the collection of migration data. Taking account of the various needs of migrant workers during program development and the planning stage can add value and relevance, and therefore, increases access to PDOs. Providing childcare services, reimbursing travel costs, and scheduling briefings near the departure date without interfering with the departure process can encourage registration and attendance. Automatic entitlement to certain social benefits upon registration in and attendance at PDOs are also innovative ways of increasing program uptake and impact (Ali 2005; Asis and Agunias 2012).

\section{Implement an effective training approach and methodology}

PDO trainers need to be qualified and trained to deliver the PDO services or briefing using modern training methods. They need to take regular refresher courses to update their skills and knowledge. In the training or briefing, it is also good practice to involve staff who represent various cultural backgrounds as well as former migrants. The curriculum must also be designed to provide comprehensive information that addresses the needs of migrants, and it should be updated regularly with the latest information from destination countries to reflect the current challenges of migrant workers.

Supporting materials such as country-specific booklets and a foreign language vocabulary handbook are also useful resources even after the PDO. In addition, supplementing the PDO with other briefing programs ensure migrant workers of comprehensive and continuous support throughout the migration process (Ali 2005; Asis and Agunias 2012).

\section{Leverage digital and technological solutions}

Digitalization has become imperative to disseminate information, collaborate with stakeholders, and continue working toward safe migration. At the predeparture stage, digital technologies - such as mobile applications, social media, online communication tools, and dedicated websitescan be leveraged to disseminate further information, supplement the PDO, and provide follow-up and accessible support services (Kikkawa, Justo, and Sirivunnabood 2021). Evidence suggests that information interventions can increase knowledge of legal rights and lead to better job performance (Shrestha and Yang 2019).

A comprehensive website created and maintained for migrants can also provide readily available information, downloadable documents, and online support to migrant users (Brestovitsky 2017). Information and communication technology gives migrant workers a platform for social connectivity (ILO 2019; Platt et al. 2014). Moreover, potential migrants become aware of the risks and opportunities of migration through informal online knowledge exchanges with peers. Overall, digital information and communication have considerable impacts on migration by diversifying and increasing opportunities (Codagnone and Kluzer 2011; Hamel 2009).

The Government of Tajikistan has undertaken efforts to make available to migrants the knowledge and information they need by enhancing digitalization. Such initiatives should continue and expand. In partnership with the International Organization for Migration (IOM), MOLME is currently developing an electronic registration system and database for migrant workers.

The Migration Service of the Republic of Tajikistan in the Russian Federation has a website containing information on the addresses and phone numbers of relevant organizations in Moscow and the names and contact details of relevant Migration Service representatives (HRC 2014). Migrant workers can use the website to open links to job portals and obtain step-by-step guidelines on employment registration and legalization in both Russian and Tajik languages. The website also contains contact information of Tajik migrants and NGOs in the Russian Federation; it does not, however, provide legal services which the Migration Service could provide to migrant workers who seek it (HRC 2014).

\section{Adopt a multistakeholder and inclusive approach}

Leveraging a multistakeholder approach can also help develop and implement a well-functioning PDO program. A decentralized PDO that involves local governments provides greater access to the service. Developing the curriculum with entities who have the resources and technical capacity enriches the content of the PDO and ensures that adequate information is provided. More importantly, capacity building of consular services and migrant representatives is crucial to strengthening their support and ties with migrants in destination countries (Ali 2005; Asis and Agunias 2012). 
It is ideal to deliver PDO in a participatory, learner-centric, and inclusive manner. Incorporating gender considerations in logistics, training content, and materials, and giving the training in the migrants' native language are some ways to promote inclusiveness. Governments should develop their own model, involve the most relevant stakeholders, and optimize their expertise. Furthermore, coordination among the different levels of government agencies should be strengthened to successfully establish more PDO centers outside urban locations and provide reliable migration information to potential migrants in far-flung areas.

\section{ENHANCING MIGRATION SERVICE CENTERS IN TAJIKISTAN}

In partnership with the Government of Tajikistan, ADB launched a Skills and Employability Enhancement project in 2018, which aims to establish three new resource-equipped migration service centers (MSCs), develop the capacity of existing migration and employment agencies, and promote awareness of migration and employment services. The new MSCs will be established in Khujand, Bokhtar, and Vose-the three major origin locations of youth labor migrants with no existing PDO centers. Human resources capacity will be improved by training all staff of MOLME and migration and employment agencies based on international best practices. In addition, an awareness-raising campaign will be conducted to promote the reformed employment and migration services (ADB 2020a).

To fill the knowledge and information gap, the new MSCs will deliver a modernized PDO and conduct new preemployment programs for migrants. MSCs will offer one-stop services to migrants who will be duly registered in a database. To help migrants land better jobs with fair living conditions in destination countries, predeparture services will provide proper orientation, a short language course and entry-level skills training. In addition, MSCs will conduct financial literacy training to inform migrants of safer remittance methods and information and communication technology training to teach ways of using technology to access information on social welfare matters. Finally, the skills certification process and capacity will be strengthened to empower Tajik migrants by improving the recognition of their skills in the regional labor market (ADB 2020a).

To modernize the PDO program, MSCs should consider key factors, such as the number, type, and capacity of institutions involved; topics or content of PDOS; duration and frequency of PDO sessions; locations of PDO programs; mode of delivery of PDOS; number of trained migrants per session; and cost of the PDOS.
Under the new undertaking, international best practices can provide some guidance in structuring the PDO program, the essential service that can address several substantial issues faced by migrant workers.

Finally, to strengthen and enhance the effectiveness of predeparture services, the impact of Tajikistan's current and future PDO program should be evaluated. This would involve identifying the program's quantifiable and unquantifiable benefits to migrants and conducting a counterfactual experiment. To monitor the impact, regular follow-up and interviews should be held with migrants after departure.

\section{CONCLUSION}

Border closures and movement restrictions imposed in response to the COVID-19 pandemic affected the livelihood and well-being of migrant workers and their families who depend heavily on remittances (Takenaka et al. 2020). As the world resumes economic activities, many major destination countries are recognizing the vital role labor migrants play in their economies. By December 2020, the Ministry of Construction Industry, Housing and Utilities of the Russian Federation had proposed to simplify the entry requirements for labor migrants from Central Asia. Kazakhstan also acknowledged a shortage of migrant workers, especially in construction.

This brief has outlined the need for effective predeparture services for Tajik migrant workers, particularly in providing them with timely and adequate knowledge and information to better explore migration opportunities post-pandemic. Policy recommendations to improve predeparture services in Tajikistan are largely drawn from insights on good practices in selected Asian countries.

Tajik migrant workers encounter issues prior to departure, such as the lack of migration-related information, high costs of migration, and lack of skills training. In destination countries, specifically in the Russian Federation, they also face unemployment, difficulty obtaining a work patent or permit leading to a reentry ban, workplace and shelter safety problems, and lack of official support from migration representatives. These issues can be mitigated through a timely and adequate predeparture orientation service. However, the predeparture centers in Tajikistan have limited capacity and resources.

The government could enhance its predeparture services by adopting good practices from selected Asian countries. It could raise awareness on available services such as skills training and predeparture orientation programs. It could also encourage attendance at predeparture orientation programs by providing social welfare incentives. The government can use digital tools to enhance predeparture services. 


\section{REFERENCES}

Ali, A. K. M. 2005. Pre-Departure Orientation Programme: Study of Good Practices in Asia (A Comparative Study of Bangladesh, the Philippines and Sri Lanka). Geneva: International Organization for Migration (IOM). http://med-mig.ips.lk/ handle/789/147.

Asian Development Bank (ADB). 2019. Skills and Employability Enhancement Project (SEEP), Republic of Tajikistan. TA Draft Final Report. Manila.

ADB. 2020a. Report and Recommendation of the President to the Board of Directors: Proposed Grant and Administration of Grant to the Republic of Tajikistan for the Skills and Employability Enhancement Project. Manila. https://www.adb.org/projects/ documents/taj-51011-003-rrp.

ADB. 2020b. Strengthening Support for Labor Migration in Tajikistan: Assessment and Recommendations. Manila. https://doi.org/10.22617/TCS200362.

Asis, M. M. B. and D. R. Agunias. 2012. Strengthening Pre-Departure Orientation Programmes in Indonesia, Nepal and the Philippines. Bangkok and Washington, DC: IOM and Migration Policy Institute. https://www.migrationpolicy.org/pubs/ PredepartureOrientation.pdf.

Barsbai, T. 2018. Pre-Departure Policies for Migrants' Origin Countries. PEGNet Policy Brief. No. 14/2018. Kiel: Kiel Institute for the World Economy (IfW), Poverty Reduction, Equity and Growth Network (PEGNet). https://www.ifw-kiel. de/fileadmin/Dateiverwaltung/PEGNet/PEGNet_Policy_ Briefs/PEGNet_Policy_Brief-14_2018.pdf.

Barsbai, T. et al. 2016. Fostering the Benefits of International Migration: A Randomized Evaluation of Pre-Departure Training for Migrants from the Philippines to the US. Paper presented at the 13th IZA Annual Migration Meeting, Bonn, Germany, 27-28 May 2016. http://conference.iza.org/conference_files/ AMM_2016/barsbai_t24041.pdf.

Brestovitsky, S. 2017. Managing the Pre-Departure Orientation Process for Armenian Labour Migrants. Basel: International Organization for Migration. p. 47. https://publications.iom. int/books/managing-pre-departure-orientation-processarmenian-labour-migrants.

Codagnone, C. and S. Kluzer. 2011. ICT for the Social and Economic Integration of Migrants into Europe. Luxembourg: Publications Office of the European Union. https://data.europa.eu/ doi/10.2791/53261.

Hamel, J.-Y. 2009. Information and Communication Technologies and Migration. Human Development Research Paper. 2009/39. United Nations Development Programme (UNDP). http://hdr.undp.org/sites/default/files/hdrp_2009_39.pdf.
Human Rights Centre (HRC). 2014. Legal Protection of Migrant Workers from Tajikistan in the Russian Federation. Dushanbe: Human Rights Centre (Tajikistan).

International Labour Organization (ILO). 2019. Mobile Women and Mobile Phones: Women Migrant Workers' Use of Information and Communication Technologies in ASEAN. Geneva. http://www.ilo.org/asia/publications/WCMS_732253/ lang--en/index.htm.

Japan International Cooperation Agency (JICA). 2020. Migration, Living Conditions and Skills: Panel Study-Tajikistan, 2018. https://www.jica.go.jp/jica-ri/publication/booksandreports/ 175nbg000019cedi-att/report_20200604.pdf.

McKenzie, D. J. 2005. Paper Walls Are Easier to Tear Down: Passport Costs and Legal Barriers to Emigration. Policy Research Working Paper. No. 3783. p. 23. Washington, DC: World Bank. https://openknowledge.worldbank.org/handle/10986/8589.

Kikkawa, A., C. Justo, and P. Sirivunnabood. 2021. Migtech: How Technology is Reshaping Labor Mobility and the Landscape of International Migration. In ADB Institute, OECD, and ILO. Labor Migration in Asia: Impacts of the COVID-19 Crisis and the Post-Pandemic Future. pp. 60-111. https://www.adb.org/ publications/labor-migration-asia-impacts-covid-19-crisispost-pandemic-future.

Platt, M. et al. 2014. Migration and Information Communications Technology Use: A Case Study of Indonesian Domestic Workers in Singapore. Migrating Out of Poverty Working Paper 24. https://assets.publishing.service.gov.uk/ media/57a089eee5274a27b200031f/WP24.pdf.

Shimizutani, S. and E. Yamada. 2021. Resilience against the Pandemic: The Impact of COVID-19 on Migration and Household Welfare in Tajikistan. JICA Ogata Research Institute Working Paper. No. 218. Tokyo: JICA Ogata Sadako Research Institute for Peace and Development. https://www.jica.go.jp/jica-ri/publication/workingpaper/ 175nbg000019q4m7-att/JICA_Ogata_Research_Institute_ WP_No218.pdf.

Forthcoming. Decision to Migrate Abroad: Evidence from Tajikistan in the 2010s.

Shrestha, S. A. and D. Yang. 2019. Facilitating Worker Mobility: A Randomized Information Intervention among Migrant Workers in Singapore. Economic Development and Cultural Change. 68(1). pp. 63-91. https://sites.Isa.umich.edu/ deanyang/wp-content/uploads/sites/205/2019/10/shresthayang-2019-facilitating-worker-mobility.pdf.

Takenaka, A. K. et al. 2020. COVID-19 Impact on International Migration, Remittances, and Recipient Households in Developing Asia. ADB Briefs. No. 148. Manila: ADB. https://doi.org/10.22617/BRF200219-2. 
About the Asian Development Bank

$A D B$ is committed to achieving a prosperous, inclusive, resilient, and sustainable Asia and the Pacific, while sustaining its efforts to eradicate extreme poverty. Established in 1966, it is owned by 68 members49 from the region. Its main instruments for helping its developing member countries are policy dialogue, loans, equity investments, guarantees, grants, and technical assistance.

ADB Briefs are based on papers or notes prepared by ADB staff and their resource persons. The series is designed to provide concise, nontechnical accounts of policy issues of topical interest, with a view to facilitating informed debate. The Department of Communications administers the series.
The views expressed in this publication are those of the authors and do not necessarily reflect the views and policies of ADB or its Board of Governors or the governments they represent. ADB encourages printing or copying information exclusively for personal and noncommercial use with proper acknowledgment of ADB. Users are restricted from reselling, redistributing, or creating derivative works for commercial purposes without the express, written consent of ADB.

Asian Development Bank 6 ADB Avenue, Mandaluyong City 1550 Metro Manila, Philippines

Tel +63286324444

Fax +63286362444

www.adb.org/publications/series/adb-briefs 